\title{
IMPACT OF SPIRULINA PLATENSIS ALGAE AND VITAMIN A SUPPLEMENTATION TO LATE PREGNANT EWES ON THEIR LAMB'S SURVIVABILITY AND PERFORMANCE
}

\author{
MABROUK A. ABD ELDAIM ${ }^{1,4}$; SAMEH. G.A. RAMADAN ${ }^{2 *}$; \\ MABROUK ELSABAGH ${ }^{3}$ and HAMADA D.H. MAHBOUB ${ }^{2}$ \\ ${ }^{1}$ Department of Biochemistry and Chemistry of Nutrition, Faculty of Veterinary, \\ Menoufia University, Sheben Elkom 32721, Egypt. \\ ${ }^{2}$ Department of Husbandry and Animal Wealth Development, Faculty of Veterinary Medicine, \\ University of Sadat City, Sadat City 32897, Egypt \\ ${ }^{3}$ Department of Nutrition and Clinical Nutrition, Faculty of Veterinary Medicine, \\ Kafr El-Sheikh University, Kafr El-Sheikh 33516, Egypt \\ ${ }^{4}$ Present address: Division of Applied Biosciences, Graduate School of Agriculture, \\ Kyoto University, 606-8502, Japan
}

Received: 30 September 2018; Accepted: 30 October 2018

\begin{abstract}
Micronutrient supplementation during late gestation can enhance the metabolic profile and physiological wellbeing of ewes and their lambs. This study was carried out to evaluate the impact of Spirulina platensis (SP) and vitamin A supplementation during late gestation on the pregnant ewes' health and their newly born lambs' viability and performance. One month before lambing, thirty six pregnant ewes $(47.4 \pm 0.52 \mathrm{~kg} \mathrm{BW})$ were randomly assigned into three experimental groups ( $\mathrm{n}=6$ with 2 replicates for each treatment) and received one of three treatments: intramuscular injection of $1 \mathrm{~mL}$ saline per ewe twice a week (control); $1 \mathrm{~g} / 10 \mathrm{~kg}$ BW of ewes /day of Spirulina platensis powder (SP) was added to the concentrate mixture; and intramuscular injection of 1 $\mathrm{mL}$ vitamin A $(50,000 \mathrm{IU})$ per ewe twice a week. Results revealed that significantly $(\mathrm{P}<0.05)$ decreased in the ewes' serum alanine aminotransferase (ALT) activity and increased the serum creatinine level of control group after lambing. However, supplementation with SP and vitamin A normalized serum ALT activity and creatinine level after lambing. Also, SP enhanced serum levels of glucose, triacylglycerol and total cholesterol after lambing. In addition, supplementation of late pregnant ewes with SP increased total leucocytes count and serum vitamin A concentration of their newly born lambs. Furthermore, SP and vitamin A supplementation to the pregnant ewes increased newly born lambs' birth weights and body temperatures, while they decreased the stillbirth by $56 \%(11.1 \%)$ and $43 \%(14.3 \%)$, respectively compared to those of the control group (25\%). Finally, SP and vitamin A ameliorated the lambing-induced stress in ewes and lambs represented by reducing serum levels of tumor necrosis factor alpha in both ewes and their lambs. Thus, supplementation of pregnant ewes with SP and vitamin A improved their health at lambing and enhanced their lambs' survivability and performance.
\end{abstract}

Key words: Spirulina platensis, vitamin A, late pregnancy, Lambing, TNF- $\alpha$.

\section{INTRODUCTION}

The transition from gestation into lactation in various domestic animals is associated with major metabolic and endocrine changes that may negatively, if not managed properly, when affect the fetal metabolism as well as the growth of the offspring postnatally (Bell, 1995; Wu et al., 2006). Several studies in sheep highlighted the importance of maternal nutrition and welfare states as driving factors controlling the magnitude of these changes

Corresponding author: SAMEH G.A. RAMADAN

E-mail address: sameh.ramadan@vet.usc.edu.eg

Present address: Department of Husbandry and Animal Wealth

Development, Faculty of Veterinary Medicine, University of Sadat City, Sadat City 32897, Egypt factors controlling the magnitude of these changes (Charismiadou et al., 2000; Yokus et al., 2006; Balıkc1 et al., 2007; Tygesen et al., 2008; Cal-Pereyra et al., 2015). The intensive metabolism and the stress of onset of lambing and lactation may compromise the metabolic profiling and antioxidative status of late pregnant ewes (Yokus et al., 2006; Balıkc1 et al., 2007; Taghipour et al., 2011). Thus, proper nutritional management, especially during the third trimester of gestation where the increase in fetal growth and udder development reach to the maximum rate (Mellor, 1983; Mellor and Murray, 1985; Robinson et al., 1999), is crucial for enhancing ewes' health and their lambs' viability. Micronutrients, trace minerals and vitamins, supplementation, to pregnant ewes can enhance the metabolic profile and physiological 
wellbeing of ewes and their lambs (Rooke et al., 2008; McCoard et al., 2017); however, studies manipulating micronutrient supplementation during late gestation are quite limited. Particularly, vitamin A received a little attention in late pregnant ewes' nutrition based on the presumption that vitamin $\mathrm{A}$ requirements could be met by its precursor $\beta$-carotene from herbage, and the hepatic store of vitamin A can buffer its deficiency (Rooke et al., 2008). In their review, Rooke et al. (2008) highlighted that pregnant ewes may experience a vitamin A depletion in practice. Vitamin A is an essential micronutrient for normal fetal development and growth as well as for the postnatal performance (Zile, 2001; Rodrigues et al., 2004; Gómez et al., 2006); however, there is no much information on the effects of vitamin A administration to late pregnant ewes on the vitamin A status of their lambs. Previous studies indicated that vitamin A supplementation to cows (Puvogel et al., 2008) and goats (Abd Eldaim et al., 2015) during late pregnancy can enhance the vitamin A status of their offspring.

As a rich source of natural micronutrients and bioactive compounds such as carotenoids, Spirulina platensis, a blue-green microalga (SP), holds promising health benefits in human and animal nutrition (Belay et al., 1996). Although an intensive research work has been conducted on the health and productivity promoting effects of SP as a functional feed supplement for various species of livestock, poultry and aquaculture (Holman and Malau-Aduli, 2013; Yaakob et al., 2014; Madeira et al., 2017), there is limited information on its benefits for pregnant ewes and their lambs. Specifically, a single study indicated that lambs born to ewes receiving a $2 \mathrm{~g} \mathrm{SP}$ day starting from the $120^{\text {th }}$ day of pregnancy have a higher growth performance than those born to control ewes (Shimkiene et al., 2010). With their inherent antioxidant and immunostimulatory properties, we hypothesize that either vitamin A or SP may enhance the health and metabolic status of Egyptian sheep, frequently subjected to nutritional stress being mainly fed on grazing pasture of fluctuated nutritive value, and consequently their offspring. Therefore, this study was carried out to evaluate the impacts of SP and vitamin A supplementation on the pregnant ewe's health and their newly born lambs' viability and performance.

\section{MATERIALS AND METHODS}

This study was carried out at the Animal Production Research Station, Kafr El-Sheikh Governorate, Egypt. All experimental procedures were approved by the Research Ethics Committee of the Faculty of Veterinary Medicine, University of Sadat City, Egypt (No: VUSC-010-1-16).

\section{Animals management and experimental design}

Eighteen ewes of Rahmani breed of the same parity and weight were synchronized for estrus using intravaginal progesterone sponges (Hamilton, New Zealand) for 14 days, followed by intramuscular injection of 400 IU of PMSG (Pregnant Mare Serum Gonadotropin, Folliogon, Intervet, Egypt) per ewe after sponge removal. Ewes were naturally inseminated with rams of the same breed, and pregnancy diagnosis was confirmed by transrectal ultrasound scanning at day 40 of pregnancy. After 120 days from breeding, the 18 pregnant ewes (47.4 \pm $0.52 \mathrm{~kg}$ average body weight) were randomly assigned into three experimental groups $(n=6)$, housed in separate pens, and received one of three treatments: intramuscular injection of $1 \mathrm{~mL}$ saline per ewe twice a week (control); SP powder was incorporated daily in the concentrate of each ewe at a rate of $1 \mathrm{~g} / 10 \mathrm{~kg} \mathrm{BW/ewe/day} \mathrm{(HERBAFORCE} \mathrm{LTD,}$ $\mathrm{UK})$; and intramuscular injection of $1 \mathrm{~mL}$ vitamin $\mathrm{A}$ (50,000 IU) per ewe twice a week. The treatments continued until lambing. The dose of SP was adopted from a previous work on fattening lambs (Elsabagh $e t$ $a l ., 2014$ ) and the vitamin A dose was adopted from a previous work on pregnant goats (Abd Eldaim et al., 2015). During the experiment, ewes were fed a common basal diet of $1.0 \mathrm{~kg} / \mathrm{h}$ ad/day of a commercial concentrate mix $(16.6 \%$ crude protein, $73.4 \%$ TDN) with free access to green fodder (Trifolium Alexandrium) and fresh drinking water. The ewes were offered $10 \mathrm{~g} /$ ewe/day of a mineral mixture containing $10 \mathrm{ppm}$ of selenium. Ewes were received anthelmintic drench, Netobimin, (Hapadex) $20 \mathrm{~mL} / 50 \mathrm{~kg}$ of body weight, (Schering-Plough Company, USA) at the beginning of the experiment. The ewes were vaccinated subcutaneously with Clostridia vaccine (Covexin, Schering-Plough Company, USA) at the $17^{\text {th }}$ week of pregnancy. Two weeks prior to the expected lambing date, the ewes were moved to large straw-bedded lambing pens.

\section{Samples collection and analyses}

Blood samples were collected from ewes at 2 weeks before lambing and from both ewes and their lambs within $2 \mathrm{~h}$ post-lambing, A 3.5-mL blood sample from each animal was taken from the Jugular vein. Each blood sample was divided into two portions. The first portion of the blood sample was placed into EDTAcontaining tubes to measure the white blood cells (WBCs) count according to Wilkinson (1981). The other portion of the blood sample was placed into non-EDTA containing tubes, left to clot at room temperature, centrifuged at $3000 \mathrm{rpm}$ for 15 minutes, and sera were kept at $-20^{\circ} \mathrm{C}$ until biochemical assay. Lambs' birth weights and rectal temperatures were recorded at $2 \mathrm{~h}$ post-lambing. The incidences of stillbirth were also recorded within $24 \mathrm{~h}$ postlambing.

Details of serum biochemical assays were previously described (EL-Sabagh et al., 2014; Abd Eldaim et al., 2015). Briefly, a calorimetric determination was performed for serum total protein and albumin 
(Young 2001), alanine aminotransferase (ALT) and aspartate aminotransferase (AST) activities (Reitman and Frankel, 1957), and triglycerides (Fossati and Prencipe, 1982). Serum globulin was calculated by subtracting albumin from total protein. Serum total cholesterol, urea, and creatinine were measured spectrophotometrically (Spekol 11, Carl Zeiss Jena, Germany) according to Allain et al. (1974); Young (2001); Larsen (1972); Coulombe and Favreau (1963), respectively. Glucose levels in whole blood were measured by a spectrophotometer (Spekol 11, Carl Zeiss Jena, Germany) according to the instructions of the manufacturer following the descriptions of Berth and Delanghe (2004). The WBCs count was determined according to Cheesbrough (2000); the blood with EDTA was diluted in 1:20 glacial acetic acid reagent which haemolyzed the red cells leaving the WBCs to be counted. The glacial acetic acid is a weak acid solution to which gentian violet was added to stain the nuclei of WBCs. Then, WBCs was counted under a microscope in a haemocytometer and the number of WBCs per litre of blood was calculated.

Serum vitamin A concentrations were spectrophotometrically determined following procedures described by Suzuki and Katoh (1990) and Abd Eldaim et al. $(2010,2015)$. In brief, $50 \mathrm{~mL}$ of ethanol and $150 \mathrm{~mL}$ of hexane was added to $50 \mathrm{~mL}$ of serum. The hexane phase was recovered after 40min mixing and $10 \mathrm{~min}$ centrifugation at $6500 \mathrm{~g}$. Vitamin A concentration was calculated based on the absorbance of hexane extracts at $325 \mathrm{~nm}$ and $453 \mathrm{~nm}$ using the equations described by Suzuki and Katoh (1990).

Serum concentrations of tumor necrosis factor alpha (TNF- $\alpha$ ) of both ewes and newly born lambs at $2 \mathrm{~h}$ after lambing were determined by using $\mathrm{TNF}-\alpha$ ELISA diagnostic kit for sheep according to the manufacturer protocol (Catalogue No. 201-07-0060; Shanghai Sunred Biological Technology Co., Ltd). Briefly, double antibody sandwich ELISA was used to assay the serum level of sheep TNF- $\alpha$. Fifty and forty $\mu \mathrm{L}$ of standard and serum respectively were added to wells that pre-coated with sheep TNF- $\alpha$ monoclonal antibody, incubated and excess antibody was washed. TNF- $\alpha$ secondary antibody labeled with biotin, and combined with Streptavidin-HRP to form an immune complex was added; incubated and finally, excess secondary antibody was washed to remove the uncombined enzyme. Then, chromogen solutions A and $\mathrm{B}$ were added, the color of the liquid changed into the blue, and the color finally becomes yellow. The optical densities of both standard and samples were read at wavelength $450 \mathrm{~nm}$ using Absorbance Microplate Reader (ELx808, BioTek, USA). Serum TNF- $\alpha$ level was calculated by using the standard curve.

\section{Statistical analysis}

The results were expressed as means \pm SE. Statistical analysis was performed by using one-way ANOVA and Fischer's post hoc test, with $\mathrm{p}<0.05$ being considered statistically significant. Stillbirth was tested using a chi-square test and are expressed as a percentage.

\section{RESULTS}

\section{Ewe's metabolic health}

The effects of SP and vitamin A supplementation on pregnant ewes' blood metabolites before and after lambing are shown in Figure 1A-C, Figure 2 and Table 1. Lambing significantly reduced $(P<0.05)$ serum ALT activity (Fig. 1A). However, it significantly increased serum level of creatinine (Fig.1B). Supplementation of pregnant ewes with SP and vitamin A normalized serum levels of ALT and creatinine after lambing, that were altered due to lambing in the control group. In addition, SP and vitamin A significantly enhanced $(P<0.05)$ blood glucose level of ewes after lambing compared to that of the corresponding control ewes (Fig.1C). To investigate whether SP and vitamin A relieve the lambing-induced stress on ewes, serum levels of TNF- $\alpha$, as stress biomarker, was quantified in ewes' serum immediately after lambing. SP and vitamin A supplementation to pregnant ewes decreased serum levels of TNF- $\alpha$ after lambing compared to that of the corresponding control group (Fig.2). In addition, SP significantly enhanced serum levels of triacylglycerol $(P<0.05)$ with a tended increase in total cholesterol $(\mathrm{P}<0.1)$ of ewes after lambing compared to those of the corresponding control ones, while vitamin A administration reduced total cholesterol in ewes postnatally (Table 1). There were no significantly differences among treatment in serum levels of total protein, albumin, globulin, AST and urea (Table 1).

\section{Lambs' survivability and performance}

The effects of SP and vitamin A supplementation to late pregnant ewes on their lambs' survivability and performance are shown in Table 2 and Figure 2. Supplementation of pregnant ewes with SP and vitamin A injection induced a significant $(P<0.05)$ and a tended $(\mathrm{P}<0.1)$ increased in serum vitamin $\mathrm{A}$ concentrations of their newly born lambs compared to those of lambs born to control ewes (Table 2). In addition, SP significantly $(P<0.05)$ increased WBCs count of their lambs compared to those of the other groups (Table 2). Both SP and vitamin A had no significant effects on serum TP, albumin, globulin, AST and ALT of lambs (Table 2). Supplementation of ewes during the late stage of pregnancy with SP and vitamin A significantly increased birth weight and body temperature of the newly born lambs compared to lambs born to the control ewes (Table 2). In addition, SP and vitamin A decreased the stillbirth of lambs by $56 \%(11.1 \%)$ and $43 \% \quad(14.3 \%)$, 
respectively, compared to those of the control group (25\%) (Table 2). Finally, SP and vitamin A ameliorated the laming-induced stress on the lambs as indicated by the significantly $(P<0.05)$ reduced serum levels of TNF- $\alpha$ of the newly born lambs compared to those of lambs born to the control group (Fig.2). Thus, SP and vitamin A supplementation to the pregnant ewes during the late stage of pregnancy enhanced their lambs' survivability and performance and relieved the lambing-induced stress in lambs.

Table 1: Effect of spirulina platensis algae and vitamin A supplementation on ewes' serum metabolites before and after lambing.

\begin{tabular}{|c|c|c|c|c|c|c|}
\hline \multirow{3}{*}{ Items } & \multicolumn{3}{|c|}{ Treatment } & & & \\
\hline & \multicolumn{3}{|c|}{ Pre-lambing } & \multicolumn{3}{|c|}{ Post-lambing } \\
\hline & Control & Vitamin A & Spirulina & Control & Vitamin A & Spirulina \\
\hline $\mathrm{TP}(\mathrm{g} / \mathrm{dl})$ & $6.16 \pm 0.14$ & $5.97 \pm 0.12$ & $5.60 \pm 0.13$ & $5.86 \pm 0.20$ & $5.56 \pm 0.12$ & $6.03 \pm 0.03$ \\
\hline Albumin (g/dL) & $3.32 \pm 0.10$ & $2.88 \pm 0.12$ & $2.88 \pm 0.11$ & $3.10 \pm 0.02$ & $2.55 \pm 0.07$ & $3.00 \pm 0.04$ \\
\hline Globulin (g/dL) & $2.84 \pm 0.16$ & $3.09 \pm 0.17$ & $2.73 \pm 0.16$ & $2.76 \pm 0.18$ & $3.05 \pm 0.11$ & $3.03 \pm 0.06$ \\
\hline AST IU & $79.7 \pm 6.19$ & $70.3 \pm 6.30$ & $78.0 \pm 6.23$ & $70.7 \pm 2.18$ & $67.7 \pm 6.33$ & $69.7 \pm 2.85$ \\
\hline Urea (mg/dL) & $40.3 \pm 7.50$ & $38.7 \pm 7.63$ & $40.4 \pm 7.37$ & $48.6 \pm 5.23$ & $52.7 \pm 1.63$ & $48.1 \pm 14.2$ \\
\hline TG (g/dL) & $31.7 \pm 5.13^{\mathrm{ab}}$ & $24.9 \pm 5.18^{b}$ & $30.4 \pm 5.10^{\mathrm{ab}}$ & $28.8 \pm 5.23^{b}$ & $30.4 \pm 2.18^{\mathrm{ab}}$ & $58.6 \pm 5.10^{\mathrm{a}}$ \\
\hline T-CHO (g/dL) & $64.9 \pm 6.62^{\mathrm{ab}}$ & $63.6 \pm 5.88^{\mathrm{ab}}$ & $82.2 \pm 7.72^{\mathrm{a}}$ & $65.0 \pm 4.64^{\mathrm{ab}}$ & $51.5 \pm 5.88^{\mathrm{b}}$ & $75.3 \pm 4.72^{\mathrm{ab}}$ \\
\hline
\end{tabular}

TP, Total protein; AST, Aspartate amino transferase; TG, Triacylglycerol; T-CHO, Total cholesterol. Data is expressed as mean \pm SE (standard error). Mean values carrying different letters in the same row are significantly different at $P<0.05$.

Table 2: Effect of spirulina platensis algae and vitamin A supplementation on newly born lambs' survivability, performance and blood indices.

\begin{tabular}{cccc}
\hline & \multicolumn{3}{c}{ Treatment } \\
\cline { 2 - 4 } Items & Control & Vitamin A & Spirulina \\
\cline { 2 - 4 } & $2.64 \pm 0.26^{\mathrm{b}}$ & $3.24 \pm 0.13^{\mathrm{a}}$ & $3.50 \pm 0.29^{\mathrm{a}}$ \\
Birth weight $(\mathrm{kg})$ & $38.4 \pm 0.18^{\mathrm{b}}$ & $38.9 \pm 0.19^{\mathrm{a}}$ & $39.3 \pm 0.20^{\mathrm{a}}$ \\
Lamb BT $\left({ }^{\circ} \mathrm{C}\right)$ & $25(4 / 16)^{\mathrm{a}}$ & $14.3(2 / 14)^{\mathrm{b}}$ & $11.1(2 / 18)^{\mathrm{b}}$ \\
Stillbirth $(\%)$ & $11.6 \pm 2.11^{\mathrm{b}}$ & $15.4 \pm 1.52^{\mathrm{ab}}$ & $17.7 \pm 1.74^{\mathrm{a}}$ \\
Vitamin A $\mu \mathrm{g} / \mathrm{mL}$ & $8.72 \pm 1.59^{\mathrm{b}}$ & $8.90 \pm 1.77^{\mathrm{b}}$ & $15.8 \pm 2.98^{\mathrm{a}}$ \\
WBCs $\left(\mathrm{x} 10^{3}\right)$ & $5.93 \pm 0.15$ & $5.38 \pm 0.15$ & $5.42 \pm 0.28$ \\
TP $(\mathrm{g} / \mathrm{dl})$ & $3.25 \pm 0.17$ & $3.03 \pm 0.13$ & $3.07 \pm 0.25$ \\
Albumin $(\mathrm{g} / \mathrm{dL})$ & $2.68 \pm 0.11$ & $2.35 \pm 0.17$ & $2.35 \pm 0.16$ \\
Globulin $(\mathrm{g} / \mathrm{dL})$ & $84.9 \pm 7.36$ & $78.3 \pm 13.3$ & $82.2 \pm 9.53$ \\
AST IU & $40.7 \pm 5.71$ & $44.8 \pm 11.1$ & $38.9 \pm 6.28$ \\
ALT IU & &
\end{tabular}

BT, Body temperature; TP, Total protein; AST, Aspartate amino transferase; ALT, Alanine amino transferase. Data is expressed as mean $\pm \mathrm{SE}$ (standard error). Mean values carrying different letters in the same row are significantly different at $P<0.05$. 


\section{$1 \mathbf{A}$}

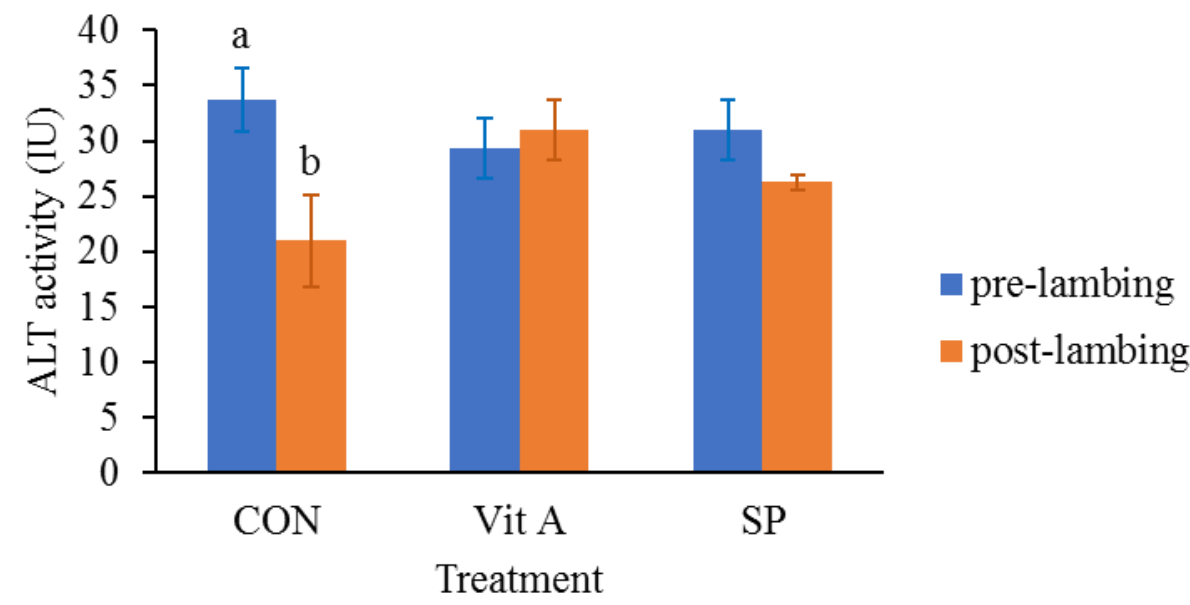

\section{B}

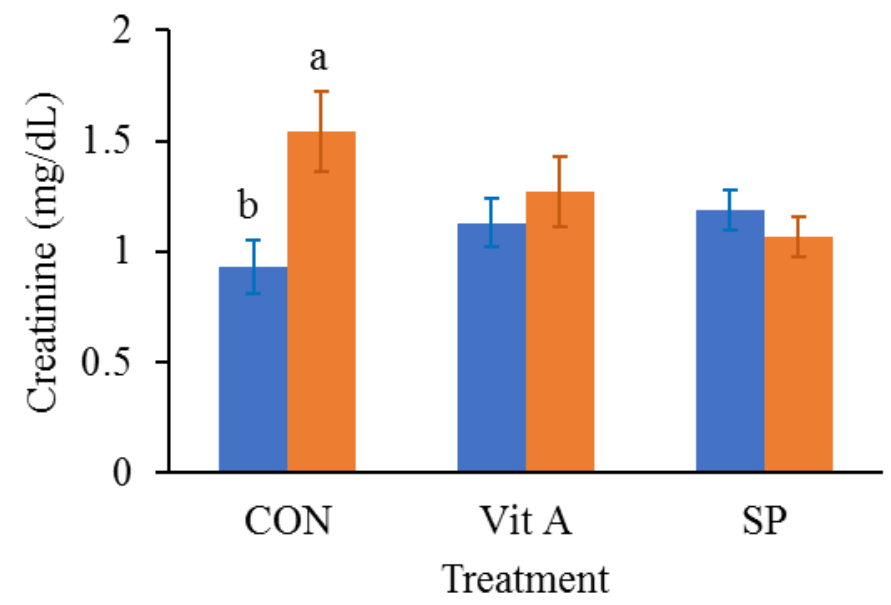

- pre-lambing

post-lambing

\section{$1 \mathrm{C}$}

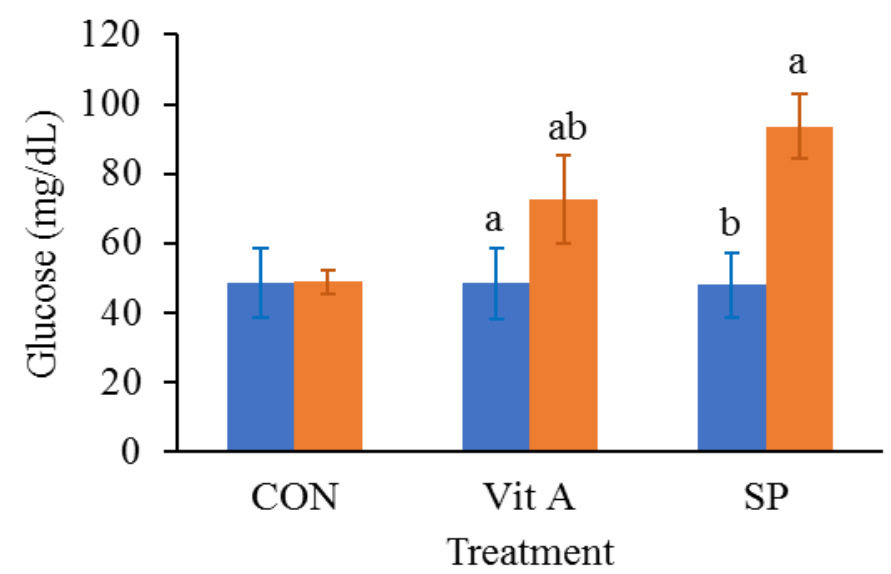

- pre-lambing

post-lambing

Fig.1: Effect of spirulina platensis algae and vitamin A supplementation to late pregnant ewes on their serum alanine amino transferase (ALT) activity (1A) and creatinine (1B) and glucose (1C) status. 


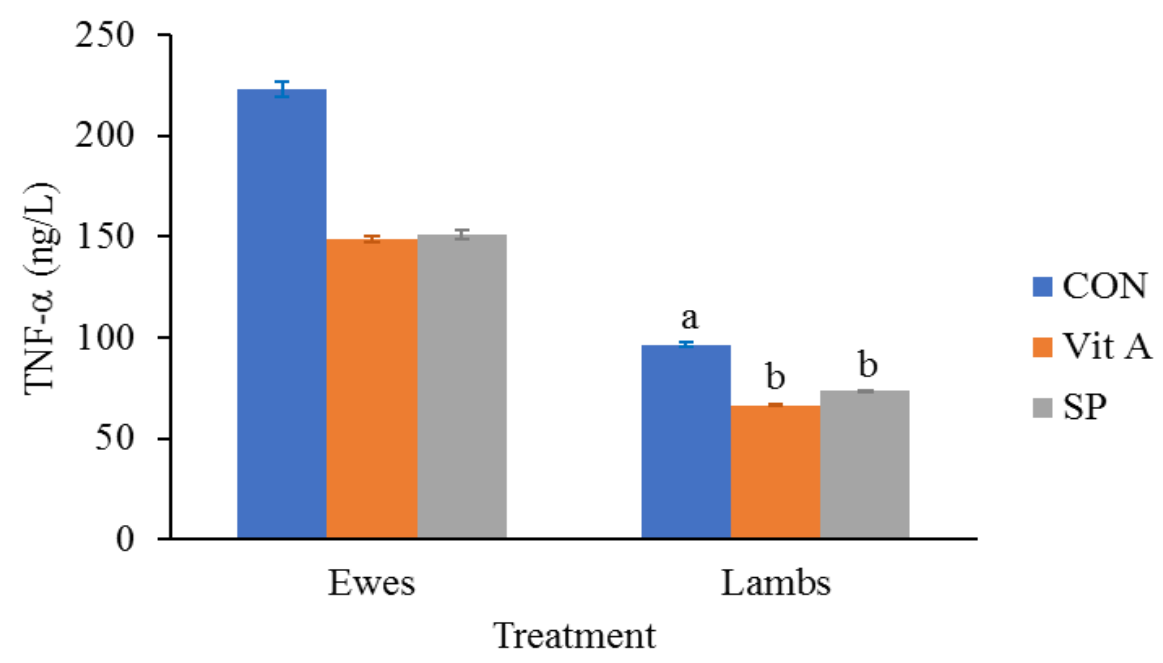

Fig.2: Effect of spirulina platensis algae and vitamin A supplementation to late pregnant ewes on serum TNF- $\alpha$ (ng/L) levels in ewes and their lambs.

\section{DISCUSSION}

The current study aimed to address the impact of prelambing SP and vitamin A administration on metabolic health of ewes and their lambs' survivability and performance and attempt to minimize the stress associated with the unavoidable nutritional stress in pregnant ewes at late stage.

Declined activity of serum ALT, elevated creatinine and TNF- $\alpha$ levels, and the persistently declined glucose concentrations in control ewes at post lambing may indicate a state of inadequate nutrition or metabolic stress associated with lambing and the onset of lactation. The ALT activity is distributed mainly in the liver and is considered as a good marker for overall health in general and for liver health in particular (Hoffmann and Solter 2008). The declined ALT activity is associated with numerous metabolic and hepatic disorders in which malnutrition may be a risk factor. Subclinical/clinical ketosis in late pregnant ewes has been associated with elevated levels of creatinine (Van Saun, 2000) and the inflammatory cytokine TNF- $\alpha$ (El-Ebissy, 2011; ELDeeb, 2012). Although glucose levels of late pregnant ewes receiving all treatments and of post-lambed control ewes of our study are far from values indicating subclinical ketosis (< 2.4-2.8 $\mathrm{mmol} / \mathrm{L}$; (Lacetera et al., 2001; Kasimanickam, 2016), it is still below, to some extent, the glucose levels of healthy ewes (50-85 mg/dl; (Jackson and Cockcroft, 2002; Pugh, 2002). Although the changes in ALT and creatinine levels are still within the normal physiological values of sheep (Jackson and Cockcroft, 2002), the accompanied declined glucose and elevated TNF- $\alpha$ indicate that the unsupplemented ewes were at risk for metabolic disorders or oxidative stress, and this risk was alleviated by administration of SP and vitamin A. Supplementation of pregnant ewes with SP and vitamin A normalized creatinine and ALT, decreased the TNF- $\alpha$ and increased glucose levels post-lambing that might be attributed to the powerful antioxidant activity of SP (Belay et al., 1996; Belay, 2002) and vitamin A (Imamura et al., 2006; Kamiloğlu et al., 2006). Previous studies demonstrated that SP (ElSabagh et al., 2014) and vitamin A (Yang et al., 2010) supplementation enhances the antioxidant activity in small ruminants. Furthermore, SP feeding enhanced serum levels of TG, cholesterol and glucose after lambing that might be due to it is a rich source of various nutrients with several health benefits (Holman and Malau-Aduli, 2013). In addition, vitamin A has been reported to increase intestinal glucose absorption and enhance insulin release and sensitivity (Tomimatsu and Horie, 2000; Blumentrath et al., 2001; Rhee and Plutzky, 2012) and this might interpret the higher glucose level with vitamin A postlaming. A similar increase in glucose was reported in pregnant goats supplemented with vitamin A prelambing (Abd Eldaim et al., 2015). Glucose is the main energy sources for fetal development and colostrum/milk production (Robinson et al., 1999; Banchero et al., 2006). Thus, with SP and vitamin A, ewes were in a positive energy status. Therefore, supplementation of pregnant ewes with SP and vitamin A decreased the lambing-induced stress on ewes and had beneficial effects on their health after lambing.

The current study showed that, the supplementation of pregnant ewes with SP and vitamin A during the late stage of pregnancy increased birth weight and body temperature of the newly born lambs, while it decreased stillbirth percentages. These findings were matched with the previous studies carried out by Shimkiene et al. (2010) who found that supplementation of pregnant ewes with SP deliver heavier lambs compared to those received no Spirulina. This finding might be due to that the 
Spirulina is rich in all essential amino acids, vitamins including vitamin A, minerals, carotenoids and fatty acids, especially gamma-linolenic acid which has several health benefits (Howe et al., 2006). Such nutrients, especially vitamin A, has been indicated to increase the birth weight and growth rate of calves born to cows injected with vitamin A during the last third of pregnancy (Salam Abdullah et al., 1987) as vitamin A transports from maternal blood of pregnant ewes to its fetus (Donoghue et al., 1985) and stimulates protein synthesis in neonatal calves (Rufibach et al., 2006). In addition, SP and vitamin A supplementation increased the rectal temperature of the newly born lambs because SP is rich in vitamin A, which has been shown to enhance the expression of brown adipose tissue mitochondrial protein, uncoupling protein, that dissipates the energy produced from nutrients metabolism in the form of heat that aid in warming the newly born animal (nonshivering thermogenesis) (Bonet et al., 2000). Therefore, supplementation of pregnant ewes with SP and vitamin A protects the newly born lambs from hypothermia, which considered one of the important causes of newly born animal's death (Rook et al., 1990).

Furthermore, SP administration to pregnant ewes increased serum vitamin A level and WBCS count in newly born lambs. This result is supported by that of El -Sabagh et al. (2014) who indicated that supplementation of fattening lambs with SP increases total leukocytic count and serum vitamin A concentration. Similar improvements in leucocytes production and activity were reported in chickens (Qureshi et al., 1996) and fish (Watanuki et al., 2006) treated with Spirulina. Increased WBCs production might be related to phycocyanin and polysaccharides contents in Spirulina as found by Zhang et al. (2001) who reported that supplementation of animals with SP polysaccharide increased WBCs counts. Also, vitamin A supplementation to late pregnant ewes tended to increase vitamin A levels in serum of their lambs. Previous studies indicated that vitamin A supplementation to cows (Puvogel et al., 2008) and goats (Abd Eldaim et al., 2015) during late pregnancy enhanced the vitamin A status of their offspring. Thus, feeding late pregnant ewes with SP and vitamin A may confer immunostimulatory properties to their lambs.

Interestingly, the results of this research revealed that feeding the pregnant ewes diets containing SP or vitamin A injection reduced lambing induced stress in ewes and newly born lambs represented by their lowering effects on serum $\mathrm{TNF}-\alpha$ levels. It was indicated that chronic mild stress or acute stress induced by injection of animals by LPS elevates serum TNF- $\alpha$ levels (Manikowska et al., 2014). SP has been shown to have a similar ameliorative effect against inflammatory diseases in animals and humans (Rasool et al., 2006; Coskun et al., 2011).
Furthermore, organic extract of SP represses TNF-- $\alpha$ expression and secretion in macrophages (Pham et al., 2016). Also, vitamin $\mathrm{A}$ and its active form alltrans retinoic acid reduce the expression of the proinflammatory cytokines interleukin 1 beta and TNF- $\alpha$ while it increases the anti-inflammatory cytokine interleukin-10 in collagen-induced arthritis in rats (Petiz et al., 2017).

Finally, SP and vitamin A supplementation to the pregnant ewes decreased the mortality rate of the newly born lambs either before or after lambing (stillbirth) by $56 \%$ and $43 \%$ respectively. This decrement of the mortality rates in the newly born lambs can be explained collectively by 1) the protective roles that may SP and vitamin A play against a wide variety of microbes as it was indicated that vitamin A deficiency in animals make them more susceptible to bacterial, viral, and parasitic infections (Chew, 1987); 2) The enhancing effects of SP and vitamin A on the animals' immunity as (Watanuki et al., 2006) found that SP enhances animal immunity while vitamin A deficiency impairs the immune function in lambs (Bruns and Webb, 1990); and 3) their protective effect against hypothermia in newly born lambs.

In conclusion, supplementation of pregnant ewes with Spirulina platensis and vitamin A during the late stage of pregnancy improved the ewes' health status after lambing through increasing and decreasing essential and toxic metabolites, respectively in ewes' serum as well as reducing the lambing-induced stress on ewes. Furthermore, they enhanced survivability and performance of the newly born lambs through protecting them from hypothermia, increasing their immunity and birth weight and reducing the lambinginduced stress on the lambs.

\section{ACKNOWLEDGMENT}

This project was supported financially by the Science and Technology Development Fund (STDF), Egypt, Grant No. 736.

\section{REFERENCES}

Abd Eldaim, M.A.; Gaafar, K.M.; Darwish, R.A.; Mahboub, H.D. and Helal, M.A. (2015): Prepartum vitamin A supplementation enhances goat doe health status and kid viability and performance. Small Ruminant Research, 129, 6-10.

Abd Eldaim, M.A.; Kamikawa, A.; Soliman, M.M.; Ahmed, M.M.; Okamatsu-Ogura, Y.; Terao, A.; Miyamoto, T. and Kimura, K. (2010): Retinol binding protein 4 in dairy cows: its presence in colostrum and alteration in plasma during fasting, inflammation, and the peripartum period. The Journal of Dairy Research, 77, 27-32. 
Allain, C.C.; Poon, L.S.; Chan, C.S.; Richmond, W. and $F u, P . C$. (1974): Enzymatic determination of total serum cholesterol. Clinical Chemistry, 20, 470-475.

Balıkcı, E.; Yıldız, A. and Gürdoğan, F. (2007): Blood metabolite concentrations during pregnancy and postpartum in Akkaraman ewes. Small Ruminant Research, 67, 247-251.

Banchero, G.E.; Perez Clariget, R.; Bencini, R.; Lindsay, D.R.; Milton, J.T.B. and Martin, G.B. (2006): Endocrine and metabolic factors involved in the effect of nutrition on the production of colostrum in female sheep. Reproduction, Nutrition, Development, 46, 447-460.

Belay, A.; Kato, T. and Ota, Y. (1996): Spirulina (Arthrospira): potential application as an animal feed supplement. Journal of Applied Phycology, 8, 303-311.

Bell, A.W. (1995): Regulation of organic nutrient metabolism during transition from late pregnancy to early lactation. Journal of Animal Science, 73, 2804-2819.

Berth, M. and Delanghe, J. (2004): Protein precipitation as a possible important pitfall in the clinical chemistry analysis of blood samples containing monoclonal immunoglobulins: 2 case reports and a review of the literature. Acta Clinica Belgica, 59, 263-273.

Blumentrath, J.; Neye, H. and Verspohl, E.J. (2001): Effects of retinoids and thiazolidinediones on proliferation, insulin release, insulin mRNA, GLUT 2 transporter protein and mRNA of INS-1 cells. Cell Biochemistry and Function, 19, 159-169.

Bonet, M.L.; Oliver, J.; Picó, C.; Felipe, F.; Ribot, J.; Cinti, S. and Palou, A. (2000): Opposite effects of feeding a vitamin A-deficient diet and retinoic acid treatment on brown adipose tissue uncoupling protein 1 (UCP1), UCP2 and leptin expression. The Journal of Endocrinology, 166, 511-517.

Bruns, N.J. and Webb, K.E. (1990): Vitamin A deficiency: serum cortisol and humoral immunity in lambs. Journal of Animal Science, $68,454-459$.

Cal-Pereyra, L.; Benech, A.; González-Montaña, J.R.; Acosta-Dibarrat, J.; Da Silva, S. and Martín, A. (2015): Changes in the metabolic profile of pregnant ewes to an acute feed restriction in late gestation. New Zealand Veterinary Journal, 63, 141-146.

Charismiadou, M.A.; Bizelis, J.A. and Rogdakis, E. (2000): Metabolic changes during the perinatal period in dairy sheep in relation to level of nutrition and breed. I. Late pregnancy. Journal of Animal Physiology and Animal Nutrition, 84, 61-72.

Cheesbrough, M. (2000): 'District Laboratory Practice in Tropical Countries.' (Cambridge
University Press)

Chew, B.P. (1987): Vitamin A and $\beta$-Carotene on Host Defense1. Journal of Dairy Science, 70, 2732 2743.

Coskun, Z.K.; Kerem, M.; Gurbuz, N.; Omeroglu, S.; Pasaoglu, H.; Demirtas, C.; Lortlar N.; Salman, B.; Pasaoglu, O.T. and Turgut, H.B. (2011): The study of biochemical and histopathological effects of Spirulina in rats with TNBS-induced colitis. Bratislavske Lekarske Listy, 112, 235-243.

Coulombe, J.J. and Favreau, L. (1963): A new simple semimicro method for colorimetric determination of urea. Clinical Chemistry, 9, 102-108.

Donoghue, S.; Richardson, D.W.; Sklan, D. and Kronfeld, D.S. (1985): Placental transport of retinol in ewes fed high intakes of vitamin A. The Journal of Nutrition, 115, 1562-1571.

EL-Sabagh, M.R.; Eldaim, M.A.A.; Mahboub, D.H. and Abdel-Daim, M. (2014): Effects of Spirulina Platensis Algae on Growth Performance, Antioxidative Status and Blood Metabolites in Fattening Lambs. Journal of Agricultural Science, 6, 92.

Fossati, P. and Prencipe, L. (1982): Serum triglycerides determined colorimetrically with an enzyme that produces hydrogen peroxide. Clinical Chemistry 28, 2077-2080.

Gómez, E.; Caamaño, J.N.; Rodríguez, A.; De Frutos, C.; Facal, N. and Díez, C. (2006): Bovine early embryonic development and vitamin A. Reproduction in Domestic Animals, Zuchthygiene, 41 Suppl, 2, 63-71.

Holman, B.W.B. and Malau-Aduli, A.E.O. (2013): Spirulina as a livestock supplement and animal feed. Journal of Animal Physiology and Animal Nutrition, 97, 615-623.

Howe, P.; Meyer, B.; Record, S. and Baghurst, K. (2006): Dietary intake of long-chain omega-3 polyunsaturated fatty acids: contribution of meat sources. Nutrition, (Burbank, Los Angeles County, Calif), 22, 47-53.

Imamura, T.; Bando, N. and Yamanishi, R. (2006): Beta-carotene modulates the immunological function of RAW264, a murine macrophage cell line, by enhancing the level of intracellular glutathione. Bioscience, Biotechnology, and Biochemistry, 70, 21122120.

Jackson, P.G.G. and Cockcroft, P.D. (2002): Clinical examination of farm animals. Clinical examination of farm animals. https://www. cabdirect.org/cabdirect/abstract/20023130074.

Kamiloğlu, N.N.; Beytut, E.; Güven, A. and Altinsaat, C. (2006): Changes in the erythrocyte antioxidant system of offspring of dams treated with Vitamin $A$ and $\beta$-carotene during gestation. Small Ruminant Research, 65, 142148.

Kasimanickam, R.K. (2016): Subclinical Pregnancy 
Toxemia-Induced Gene Expression Changes in Ovine Placenta and Uterus. Frontiers in Veterinary Science, 3, 69.

Lacetera, N.; Bernabucci, U.; Ronchi, B. and Nardone, A. (2001): Effects of subclinical pregnancy toxemia on immune responses in sheep. American Journal of Veterinary Research, 62, 1020-1024.

Larsen, K. (1972): Creatinine assay in the presence of protein with LKB 8600 Reaction Rate Analyser. Clinica Chimica Acta; International Journal of Clinical Chemistry, 38, 475-476.

Madeira, M.S.; Cardoso, C.; Lopes, P.A.; Coelho, D.; Afonso, C.; Bandarra, N.M. and Prates, J.A.M. (2017): Microalgae as feed ingredients for livestock production and meat quality: A review. Livestock Science, 205, 111-121.

Manikowska, K.; Mikołajczyk, M.; Mikołajczak, P.Ł. and Bobkiewicz-Kozłowska, T. (2014): The influence of mianserin on TNF- $\alpha$, IL-6 and IL10 serum levels in rats under chronic mild stress. Pharmacological reports: PR, 66, 2227. doi: 10.1016/j.pharep.2013.06.003.

McCoard, S.A.; Sales, F.A. and Sciascia, Q.L. (2017): Invited review: impact of specific nutrient interventions during mid-to-late gestation on physiological traits important for survival of multiple-born lambs. Animal: An International Journal of Animal Bioscience, 11, 1727-1736.

Mellor, D.J. (1983): Nutritional and Placental Determinants of Foetal Growth Rate in Sheep and Consequences for the Newborn Lamb. British Veterinary Journal, 139, 307-324.

Mellor, D.J. and Murray, L. (1985): Effects of maternal nutrition on udder development during late pregnancy and on colostrum production in Scottish Blackface ewes with twin lambs. Research in Veterinary Science, 39, 230-234.

Petiz, L.L.; Kunzler, A.; Bortolin, R.C.; Gasparotto, J.; Matté, C.; Moreira, J.C.F. and Gelain, D.P. (2017): Role of vitamin A oral supplementation on oxidative stress and inflammatory response in the liver of trained rats. Applied Physiology, Nutrition, and Metabolism "Physiologie Appliquee, Nutrition Et Metabolisme”, 42, 1192-1200.

Pham, T.X.; Park, Y.K. and Lee, J.Y. (2016): AntiInflammatory Effects of Spirulina platensis Extract via the Modulation of Histone Deacetylases. Nutrients, 8, 6. doi:10.3390/ nu8060381.

Pugh, D.G. (2002): 'Sheep \& Goat Medicine.' (Saunders)

Puvogel, G.; Baumrucker, C. and Blum, J.W. (2008): Plasma vitamin A status in calves fed colostrum from cows that were fed vitamin A during late pregnancy. Journal of Animal Physiology and Animal Nutrition, 92, 614620.

Qureshi, M.A.; Garlich, J.D. and Kidd, M.T. (1996):
Dietary Spirulina Platensis Enhances Humoral and Cell-Mediated Immune Functions in Chickens. Immunopharmacology and Immunotoxicology, 18, 465-476.

Rasool, M.; Sabina, E.P. and Lavanya, B. (2006): Anti-inflammatory effect of Spirulina fusiformis on adjuvant-induced arthritis in mice. Biological \& Pharmaceutical Bulletin, 29, 2483-2487.

Reitman, S. and Frankel, S. (1957): A colorimetric method for the determination of serum glutamic oxalacetic and glutamic pyruvic transaminases. American Journal of Clinical Pathology, 28, 56-63.

Rhee, E.J. and Plutzky, J. (2012): Retinoid metabolism and diabetes mellitus. Diabetes \& Metabolism Journal, 36, 167-180.

Robinson, J.J.; Sinclair, K.D. and McEvoy, T.G. (1999): Nutritional effects on foetal growth. Animal Science, 68, 315-331.

Rodrigues, P.; Goncalves, C. and Bairos, V. (2004): Metabolic Pathways and Modulating Effects of Vitamin A. doi:info:doi/10.2174/ 1568013043357879.

Rook, J.S.; Scholman, G.; Wing-Proctor, S. and Shea, M. (1990): Diagnosis and Control of Neonatal Losses in Sheep. Veterinary Clinics of North America: Food Animal Practice, 6, 531-562.

Rooke, J.A.; Dwyer, C.M. and Ashworth, C.J. (2008): The potential for improving physiological, behavioural and immunological responses in the neonatal lamb by trace element and vitamin supplementation of the ewe. Animal: An International Journal of Animal Bioscience, 2, 514-524.

Rufibach, K.; Stefanoni, N.; Rey-Roethlisberger, V.; Schneiter, P.; Doherr, M.G.; Tappy, L. and Blum, J.W. (2006): Protein synthesis in jejunum and liver of neonatal calves fed vitamin A and lactoferrin. Journal of Dairy Science, 89, 3075-3086.

Salam Abdullah, A.; Vijchulata, P.; Sivarajasingam, S. and Ragavan, K. (1987): Haematologic and growth response to prepartum administration of vitamin A in calves. Growth, 51, 198-201.

Shimkiene, A.; Bartkevichiute, Z.; Chernauskiene, J.; Shimkus, A.; Chernauskas, A.; Ostapchuk, A. and Nevitov, M. (2010): The influence of Spirulina platensis and concentrates on lambs' growth. Zhivotnov'dni Nauki, 47, 9-14.

Suzuki, J. and Katoh, N. (1990): A simple and cheap methods for measuring serum vitamin $\mathrm{A}$ in cattle using only a spectrophotometer. Nihon Juigaku Zasshi The Japanese Journal of Veterinary Science, 52, 1281-1283.

Taghipour, B.; Seifi, H.A.; Mohri, M.; Farzaneh, N. and Naserian, A. (2011): Variations of Energy Related Biochemical Metabolites During Periparturition Period in Fat-Tailed Baloochi Breed Sheep. Iranian Journal of Veterinary Science and Technology, 2, 85-92. 
Tomimatsu, T. and Horie, T. (2000): Enhanced absorption of 3-O-methyl-D-glucose through the small intestine of rats administered retinyl palmitate. Research Communications in Molecular Pathology and Pharmacology, 107, 349-360.

Tygesen, M.P.; Nielsen, M.O.; Nørgaard, P.; Ranvig, H.; Harrison, A.P. and Tauson, A.H. (2008): Late gestational nutrient restriction: effects on ewes' metabolic and homeorhetic adaptation, consequences for lamb birth weight and lactation performance. Archives of Animal Nutrition, 62, 44-59.

Van Saun, R.J. (2000): Pregnancy toxemia in a flock of sheep. Journal of the American Veterinary Medical Association, 217, 1536-1539.

Watanuki, H.; Ota, K.; Tassakka, A.C.M.A.R.; Kato, T. and Sakai, M. (2006): Immunostimulant effects of dietary Spirulina platensis on carp, Cyprinus carpio. Aquaculture, 258, 157-163.

Wu, G.; Bazer, F.W.; Wallace, J.M. and Spencer, T.E. (2006): Board-invited review: intrauterine growth retardation: implications for the animal sciences. Journal of Animal Science, 84, 2316-2337.

Yaakob, Z.; Ali, E.; Zainal, A.; Mohamad, M. and Takriff, M.S. (2014): An overview: biomolecules from microalgae for animal feed and aquaculture. Journal of Biological Research, 21, 1: (6). doi:10.1186/2241-579321-6.

Yang, W.; Wang, P.; Jing, Y.; Yang, Z.; Zhang, C.; Jiang, S.; Zhang, G.; Yang, W.; Wang, P.; Jing, $Y$.; Yang, Z.; Zhang, C.; Jiang, S. and Zhang, G. (2010): Effects of Vitamin A on Growth Performance, Antioxidant Status and Blood Constituents in Lactating Grey Goat. American Journal of Animal and Veterinary Sciences, 5, 274-281.

Yokus, B.; Cakir, D.U.; Kanay, Z.; Gulten, T. and Uysal, E. (2006): Effects of seasonal and physiological variations on the serum chemistry, vitamins and thyroid hormone concentrations in sheep. Journal of Veterinary Medicine A, Physiology, Pathology, Clinical Medicine, 53, 271-276.

Zhang, H.Q.; Lin, A.P.; Sun, Y. and Deng, Y.M. (2001): Chemo- and radio-protective effects of polysaccharide of Spirulina platensis on hemopoietic system of mice and dogs. Acta Pharmacologica Sinica, 22, 1121-1124.

Zile, M.H. (2001): Function of vitamin A in vertebrate embryonic development. The Journal of Nutrition, 131, 705-708.

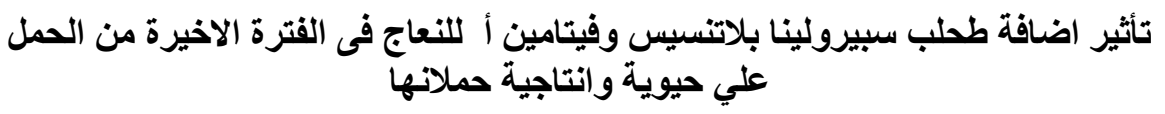

مبروك عطية عبل الد/يم ، سامح جاد عبل الحق رمضان ، مبرولك الصباغ ، حمادة ضاحى حسين محبوب

Email: sameh.ramadan@vet.usc.edu.eg Assiut University web-site: www.aun.edu.eg

اجريت هذه التجربة لدراسة تاثير اضافة طحلب سبيرولينا بلاتتسيس وحقن فيتامين أ للنعاج فى الفترة الاخيرة من الحمل على صحة

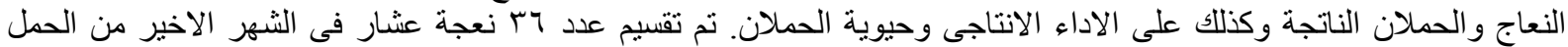

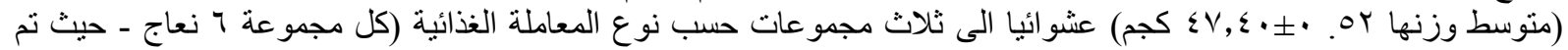

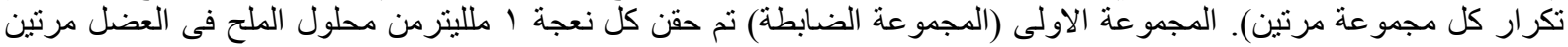

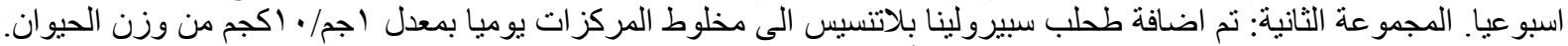

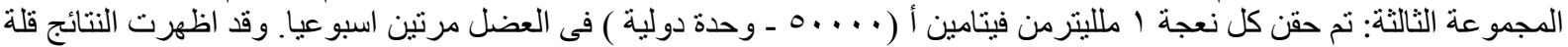

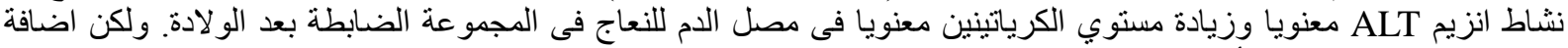

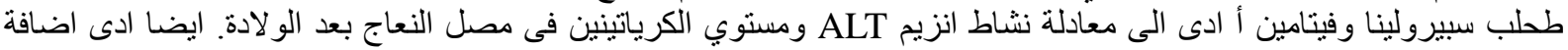

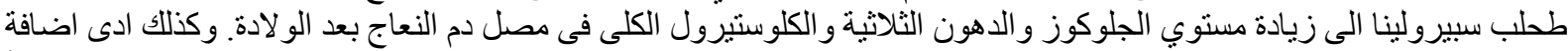

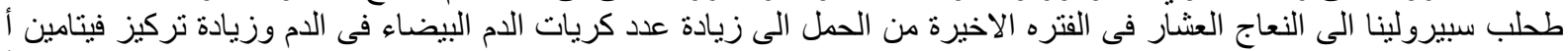

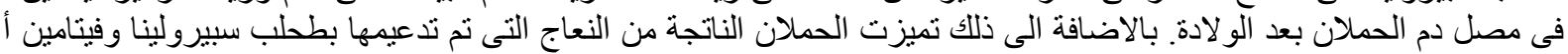

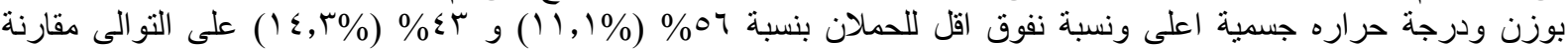

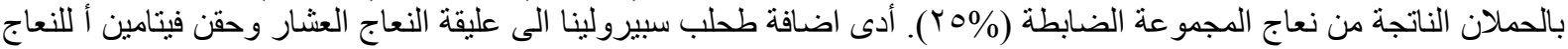

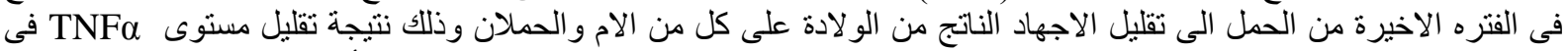

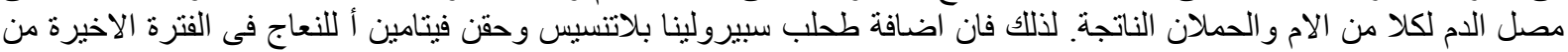

الحمل ادى الى تحسن صحتها عند الو لادة وتعزيز انتاجية وحيوية حملانها. 